\title{
Design of PLGA-based Scaffolds for Developing and Differentiating Mesenchymal Stem Cells (MSCs)
}

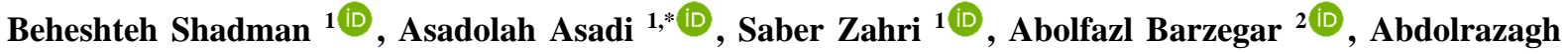 \\ Marzban 3, * (D) \\ 1 Department of Biology, Faculty of Science, University of Mohaghegh Ardabili, Ardabil, Iran; bshzist@ yahoo.com (B.S); \\ asad.asady@gmail.com (A.A); sazahri@gmail.com (S.Z); \\ 2 Research institute Fundamental Science, University of Tabriz, Tabriz- Iran; barzegar@tabrizu.ac.ir (A.B); \\ 3 Razi Herbal Medicines Research Center, Lorestan University of Medical Sciences, Khorramabad, Iran; \\ marzban86@gmail.com (A.A); \\ * Correspondence: Marzban86@gmail.com (A.M.); asad.asady@gmail.com (A.A.);
}

Scopus Author ID 53463276000

Received: 20.12.2020; Revised: 20.01.2021; Accepted: 24.01.2021; Published: 31.01.2021

\begin{abstract}
In recent years, bone tissue engineering using cells, biomolecules, and scaffolds have made significant progress in the acute treatment of bone defects. In this study, a PLGA polymeric scaffold $(40 / 60)$ was fabricated by solvent casting/salt leaching method using porogen $(\mathrm{NaCl})$. The results of the structural analysis of the PLGA scaffold showed moderate porosity with pore sizes of 50 to $200 \mu \mathrm{m}$. Degradation of PLGA scaffold was found to be $80 \%$ for 80 hours as submerged in water. Water absorption by the scaffold was about $268.81 \%$ for $24 \mathrm{~h}$ of immersion. Cell biocompatibility tests showed optimal growth of LNCaP cell line on the scaffold. The growth and differentiation of MSCs on the scaffold occurred over a period of 21 days, which was confirmed by evaluating the expression of alkaline phosphatase (Alp) and osteopontin (Ops) genes. The amount of calcification of differentiated cells also confirmed the differentiation of MSCs into osteoblasts. Taken together, PLGA-based polymer scaffolds could potentially be used for tissue engineering, implant design, and drug delivery systems.
\end{abstract}

Keywords: PLGA scaffold; mesenchymal stem cells; tissue engineering; cell differetiation.

(C) 2021 by the authors. This article is an open-access article distributed under the terms and conditions of the Creative Commons Attribution (CC BY) license (https://creativecommons.org/licenses/by/4.0/).

\section{Introduction}

Tissue engineering is an emerging biological technique in which damaged tissues or cells are replaced with healthy ones [1]. The primary purpose of tissue engineering is to design biological structures to repair, maintain, or improve tissue function and their clinical application destroyed by tissue damage due to trauma or disease. The function of scaffolds is to support seed cells inside the porous scaffold structure to differentiate into specific tissue. Since most mammalian cells are anchorage-dependent, they can not differentiate without binding to the substrate [2].

Therefore, scaffolds should provide a suitable backbone for cell attachment, proliferation, differentiation, and cell migration [3]. Besides, biopolymeric scaffolds could be used to implant and differentiate stem cells at particular tissue sites. These scaffolds establish a porous $3 \mathrm{D}$ structure with a large surface-to-volume ratio that enables cells to bind to it by creating extracellular adhesive molecules [4]. One of the unique advantages of biological scaffolds is their biocompatibility, which facilitates the development of the cells' vascular 
network in the scaffolding site and subsequently directs the resulting cell mass towards organogenesis [5,6].

Various materials, such as natural or synthetic polymers, are used to manufacture tissue scaffolds. A combination of natural and synthetic materials is often applied as a copolymer. Tissue engineering scaffolds based on synthetic polymers are preferred because natural polymers are more costly and less readily available. Natural polymers can also cause various biological pollutants, such as bacterial and viral pathogens [2,3].

On the other hand, synthetic polymers are easily manipulated and are often biologically inert. Accordingly, their structural features, such as molecular weight and porosity, can be controlled according to the human body's physical and mechanical characteristics. There are mainly two kinds of synthetic polymers, namely biodegradable and non-biodegradable polymers [7].

Synthetic degradable polymers are preferred for scaffolding tissue engineering scaffolds because they minimize the body's chronic external reactions leading to normal tissue regeneration. Three-dimensional scaffolding architecture with appropriate pore size, alignment, and interconnection can significantly affect the regulation of tissue-specific morphogenesis of cultured cells [2,3]. As a result, the growth rate of tissue increases with an improvement in embedded scaffolds' porosity. Therefore, the scaffolds' structure can significantly impact the transport of nutrients and oxygen into the 3D matrix, which can directly change the motility of cells during tissue regeneration [8]. The pores' average diameter must be large enough for the cells to migrate and small sufficient to maintain the total critical surface for proper cell attachment. The size of the scaffold pores can affect cell adhesion, growth, and phenotype. The scaffold pores' optimum size, which allows for maximum cell entry and cell adhesion and matrix deposition, varies among different cell types [9]. In this study, PLGA scaffolds have been produced with desirable biocompatibility and biodegradability. Suitable porosity of PLGA scaffolding and surface adhesion improves the attachment of MSCs, which, in turn, could provide a sound stage for the development of tissues and organ engineering.

\section{Materials and Methods}

\subsection{PLGA scaffold fabrication.}

Porous scaffolds of poly (lactic-co-glycolic acid)(PLGA) were synthesized using a solvent casting/salt leaching process. Briefly, $0.5 \mathrm{~g}$ of PLGA was added to $6 \mathrm{ml}$ of chloroform in a beaker. The PLGA powder was completely dissolved in a water bath at $60^{\circ} \mathrm{C}$ for $45 \mathrm{~min}$. For scaffold synthesis, $4 \mathrm{~g}$ of sodium chloride $(\mathrm{NaCl})$ was added to the solution and mixed well with a glass rod. Subsequently, the mixture was poured into a Teflon-coated Petri dish and kept at room temperature for $12 \mathrm{~h}$. Finally, the remaining chloroform was removed from the scaffold by placing it in a vacuum desiccator overnight. To fabricate the scaffold, $4 \mathrm{~g}$ of sodium chloride $(\mathrm{NaCl})$ was added to the solution and mixed well with a glass rod. Subsequently, the mixture was poured into a Teflon-coated Petri dish and kept at room temperature for $12 \mathrm{~h}$. Finally, the residual chloroform was removed from the scaffold by placing it in a vacuum desiccator overnight. Desalting of the polymeric scaffold was performed by immersing it in deionized water $\left(\mathrm{dH}_{2} \mathrm{O}\right)$ for $72 \mathrm{~h}$, in which its water was replaced after the 6-h periods [10]. 


\subsection{Scaffold analysis by scanning electron microscopy (SEM).}

The surface morphology and scaffold pores were examined by scanning electron microscopy (sem). Scaffold samples were cut into $2 \times 5 \mathrm{~cm}$ pieces and then coated with gold using a steaming method. Electron microscope images were taken by SEM FEI Quanta 200 (Eindhoven, Netherlands) at 100× magnification with a scale bar of $100 \mu \mathrm{m}$.

\subsection{Pore size and porosity measurement.}

The pore size of the scaffold cross-section was determined from SEM images using ImageJ software. Scaffold porosity was studied using the Archimedes' Principle. Briefly, a graduated bottle was used to measure the scaffold's density and porosity [11]. The density of ethanol ( $\rho$ e) was measured as a displacement fluid at $30^{\circ} \mathrm{C}$. First, the weight of the cylinder filled with ethanol $\left(\mathrm{W}_{1}\right)$ was determined. Then, the scaffold sample with a certain weight $(\mathrm{Ws})$ was immersed in the cylinder and weighed again $\left(\mathrm{W}_{2}\right)$. After $1 \mathrm{~h}$, the ethanol-saturated scaffold was removed, and the weight of the cylinder was measured $\left(\mathrm{W}_{3}\right)$. The degree of porosity of the scaffold was determined using the following formula:

$$
\begin{aligned}
& \mathrm{Vp}=\left(\mathrm{W}_{2}-\mathrm{W}_{3}-\mathrm{Ws}\right) / \rho \mathrm{e} \\
& \mathrm{Vs}=\left(\mathrm{W}_{1}-\mathrm{W}_{2}+\mathrm{Ws}\right) / \rho \mathrm{e}
\end{aligned}
$$

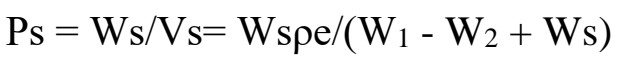

$$
\begin{aligned}
& \varepsilon=\mathrm{Vp} /(\mathrm{Vp}+\mathrm{Vs})=\left(\mathrm{W}_{2}-\mathrm{W}_{3}-\mathrm{Ws}\right) /\left(\mathrm{W}_{1}-\mathrm{W}_{3}\right)
\end{aligned}
$$

where, $\rho e, \varepsilon, \mathrm{Vp}$ and $\mathrm{Vs}$ are the scaffold density, the porosity, the volume of the scaffold pore and scaffold skeleton, respectively.

\subsection{Water absorption assay.}

The water absorption capacity, weight loss assay, and PH changes of PLGA scaffold samples were investigated for $80 \mathrm{~h}$. The pre-weighed scaffold samples were immersed in phosphate-buffered saline solution (PBS, pH 7.5) at $37{ }^{\circ} \mathrm{C}(\mathrm{PBS})$ and then weighed. The scaffold blocks were immersed in PBS, and 3 samples were taken every $8 \mathrm{~h}$. Afterward, the wet samples were weighed, and the percentage of water absorption was determined according to the following formula:

$$
\mathrm{W}_{\mathrm{Ab}}=\left(\mathrm{W}_{\mathrm{a}}-\mathrm{W}_{0}\right) / \mathrm{W}_{0} \times 100 \%
$$

\subsection{PLGA scaffold degradation test.}

Samples of scaffolds in the dimension of $1 \times 1 \times 2 \mathrm{~cm}^{3}$ weighing $\left(\mathrm{W}_{0}\right)$ were then sterilized for $10 \mathrm{~min}$ by UV radiation exposure. The samples were placed in $50 \mathrm{ml}$ falcon tubes containing $5 \mathrm{ml}$ phosphate buffer saline (PBS) and incubated at $37^{\circ} \mathrm{C}$. In an 8-day experiment, 3 samples were taken daily and washed with deionized water after weighing $\left(\mathrm{W}_{\mathrm{a}}\right)$ and dried in a freeze drier apparatus. Finally, water absorption $\left(\mathrm{W}_{\mathrm{A}} \%\right)$ and weight loss $\left(\mathrm{W}_{\mathrm{L}} \%\right)$ were calculated as follows [11]:

$$
\begin{aligned}
& \mathrm{W}_{\mathrm{A}}=\left(\mathrm{W}_{\mathrm{a}}-\mathrm{W}_{0}\right) / \mathrm{W}_{0} \times 100 \% \\
& \mathrm{~W}_{\mathrm{L}}=\left(\mathrm{W}_{0}-\mathrm{W}_{\mathrm{t}}\right) / \mathrm{W}_{0} \times 100 \%
\end{aligned}
$$

\subsection{Cell Compatibility of the PLGA scaffold.}

The LNCaP cell line was used to evaluate biological responses in vitro, which was purchased from the National Cell Bank of Iran, Pasteur Institute. LNCaP cells were cultured in 
RPMI supplemented with $10 \%$ fetal serum (FBS) and 1\% streptomycin/penicillin. LnCaP cells with $80 \%$ confluency were used for seeding to the PLGA scaffold. For this purpose, cells were separated from the flasks with $0.25 \%$ trypsin-EDTA. Then $2 \times 10^{5}$ cells $/ \mathrm{ml}$ were counted, mixed with fresh medium, and seeded onto the PLGA scaffold $\left(1 \times 1 \times 0.2 \mathrm{~cm}^{3}\right)$ in a 12-well plate. Cell adhesion study was conducted after $4 \mathrm{~h}$ incubation at $37{ }^{\circ} \mathrm{C}$ and $5 \% \mathrm{CO}_{2}$. Unattached cells were removed from the PLGA scaffold and washed using PBS. Then, adhered cells were monitored by an inverted microscope, and SEM images were provided from them.

\subsection{Isolation and purification of mesenchymal stem cells (MSCs).}

A total of 12 rats of Wistar strain (aged 7 weeks; weighing 150-200 g) were purchased from the Institute of Pasteur of Iran and kept in standard conditions per laboratory animal care protocols. Bone marrow-derived MSCs were isolated and purified according to the method of Sukanya et al. (2018) [12]. The femur and tibia of fully anesthetized rats were excised under aseptic conditions and carefully removed connective tissue attached to the bones. Bone marrow cells were extracted by flushing the bone cavity with DMEM culture medium containing $10 \%$ bovine fetal serum (FBS), $100 \mathrm{IU} / \mathrm{ml}$ penicillin, and $100 \mathrm{~g} / \mathrm{ml}$ streptomycin. After harvesting the cell suspension, they were centrifuged at $3000 \mathrm{rpm}$ for $5 \mathrm{~min}$, resuspended in the fresh medium, and incubated in a humidified atmosphere at $5 \% \mathrm{CO}_{2}$ at $37{ }^{\circ} \mathrm{C}$ for $72 \mathrm{~h}$. Afterward, the culture medium was discarded from the flasks and washed with PBS. The adhered cells were treated with $1 \mathrm{ml}$ of 0.25 percent trypsin-EDTA to detach MSCs established in the bone marrow. Finally, MSCs were transferred to other flasks and used for subsequent steps. Also, MSCs were prepared from cryovial and stored in liquid nitrogen.

\subsection{MSCs seeding in PLGA scaffold.}

For cell seeding, the PLGA scaffold was poured into a 5-well plate and sterilized by UV irradiation. Then $200 \mu \mathrm{l}$ of cell suspension $\left(10^{4}\right.$ cells $\left./ \mathrm{ml}\right)$ was placed on PLGA scaffold blocks. For allowing to attach the cells, the plates were incubated in a $\mathrm{CO}_{2}$ incubator for 1 . Subsequently, the Scaffold-attached cells were supplemented with $1 \mathrm{ml} \alpha$-MEM containing $10 \%$ fetal bovine serum and incubated for $12 \mathrm{~h}$ at $37{ }^{\circ} \mathrm{C}$ in $5 \% \mathrm{CO}_{2}$ with $95 \%$ humidity.

\subsection{Differentiation and mineralization study.}

Scaffold-attached MSCs were stimulated to differentiate into osteoblastic cells. For this, the culture medium of scaffold-attached MSCs was discarded and replaced with an osteogenic medium, $\alpha$-MEM consisting of $50 \mu \mathrm{g} / \mathrm{ml}$ of ascorbic acid, $10 \mathrm{nM}$ dexamethasone, and $10 \mathrm{mM}$ of $\beta$-glycerol phosphate. Osteoblastic differentiation was assessed by Alizarin red staining, which confirms the growth of calcium nodes in cells. The medium was changed every 3-4 days. After 21 days of incubation, the medium was discarded, and the scaffold-attached cells were washed with PBS. After that, the cells were fixed in formalin (40\%) and stained with Alizarin red $1 \%$. Non-differentiated MSCs were stained as a negative control. Additionally, SEM images were taken to investigate the calcification process.

\subsection{Molecular analysis of differentiation.}

Expression of two genes related to differentiation, alkaline phosphatase and osteopontin, were evaluated in the first, second, and third weeks by the Real-Time PCR method. $\beta$-actin was used as an internal control. Total RNA was extracted after the first, second, 
and third weeks of scaffold-attached cells cultivated in the differentiation medium. Briefly, cells were washed by PBS, transferred to $1 \mathrm{ml}$ microtubes, and extracted with TRIzol reagent (Invitrogen). RNA was converted to cDNA using a cDNA synthesis kit (Takara, Ohtsu, Japan). The qPCR reaction was performed in a Corbett Rotor-Gene 6000 system (Qiagen, USA). Primer sequences were: ALP: F(5'- CCATCGGACCCTGCCTTACCAAC-3') and R (5'GCCCACGGACTTCCCAGCATC-3')];

Osteopontin:

$\left[\mathrm{F}\left(5^{\prime}-\right.\right.$ TCACCATTCGGATGAGTCTG-3') and R(5'-ACTTGTGGCTCTGATGTTCC-3') and $\beta$ Actin: $\quad$ F(5'-TGGAGAAATCTGGCACCACACC-3') and ${ }^{\prime}$ R (5'GATGGGCACAGTGTGGGTGACCC-3').

\subsection{Statistical analysis.}

The results were statistically analyzed by GraphPad Prism 6 (GraphPad Software Inc., $\mathrm{CA}$ ) in a randomized design. The data are presented as mean $\pm \mathrm{SD}$. The comparison was performed via a one-way analysis of variance (ANOVA) followed by posthoc Tukey tests at a $95 \%$ confidence interval. The p-value $<0.05$ was considered statistically significant.

\section{Results and Discussion}

\subsection{SEM image analysis.}

Synthesis of PLGA scaffold based on the solvent casting/salt leaching technique with a ratio of 60:40 of PLGA:sodium chloride $(\mathrm{NaCl})$ resulted in the formation of the highly porous structure. SEM micrographs of the synthesized PLGA scaffold show roughness on the scaffold surface (Fig. 1A). The cross-sectional analysis confirmed the high-level interconnections in the scaffold polymer structure (Fig. 1B). In general, studies show that increasing the amount of salt, followed by extending the blending time, increases both porosity and surface roughness [13]. Salinity plays a vital role in the cross-linking of PLGA polymers. Since PLGA is hydrated, sodium chloride interacts with PLGA polymer to form a cross-link. Consequently, sodium chloride affects PLGA scaffolds' porosity by the polymerization and cross-bridge formation [14].

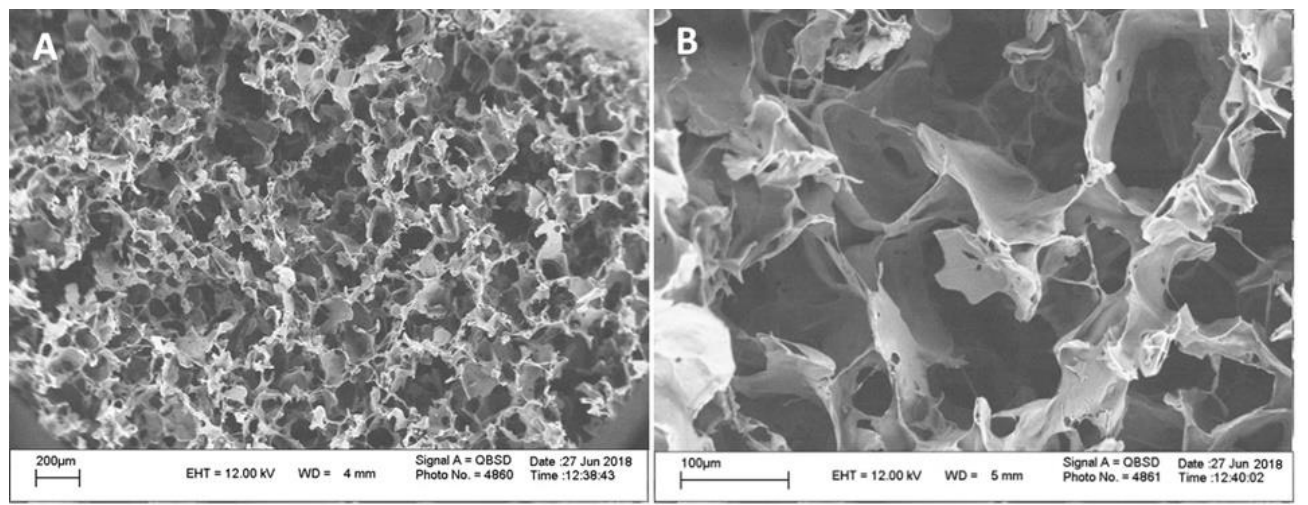

Figure 1. SEM image of the PLGA scaffold. (A) high porous structure of the scaffold and Cross-section of PLGA Scaffold indicates interconnections of the scaffold structure.

Scaffold surface roughness is a critical factor in cell attachment. Some extracellular adhesive proteins and molecules preferably attach to more rough surfaces. Studies show that increasing the dimension and roughness of polymer scaffolds increases the adhesion of 
extracellular matrix (ECM) so that cells on 3D structures have significantly more proliferation, differentiation, and survival than two-dimensional ones $[15,16]$.

\subsection{Porosity, water absorptoion and degradation assay.}

The pore size distribution calculated by Image J showed to be 50 to $200 \mu \mathrm{m}$ in diameter (Figure 2A). However, the largest pores were estimated in the range of 100 to $150 \mu \mathrm{m}$. The porosity percentage, also determined by the Archimedes principle, was about $90.1 \%$, with a density of $7.49 \mathrm{~g} / \mathrm{cm} 3$. Figure $2 \mathrm{~B}$ shows the water absorption curve of the PLGA scaffold in PBS for $80 \mathrm{~h}$. By day 16, the highest water absorption was about $268.81 \%$. After that, water absorption by PLGA scaffolding remained stable. As seen in figure $2 \mathrm{~B}$, weight loss, which meant scaffold destruction, was faster in the first 24 days, estimating about $43 \%$ of weight loss during this time. After that, the degradation rate was slightly slower, with approximately $78 \%$ of the scaffold degraded within $80 \mathrm{~h}$. Besides, with the scaffold degradation, the $\mathrm{pH}$ reached the initial value of 7.4 to 6.4 on the 80th day. It has been reported that water absorption on a scaffold could facilitate the degradation of PLGA scaffold into lactic acid and glycolic acid [17]. High water absorption may facilitate the scaffold's hydrolysis through the interaction between water molecules and the polymer matrix and lead to faster degradation [18]. The assessment of scaffold degradation revealed a depletion of approximately $44.44 \%$ within 24 days. Such observations vary from other studies' findings that indicated many parameters, such as molecular weight, fragment size, structure, and environmental conditions, are involved in the degradation process $[19,20]$. Influential factors in the biocompatibility of scaffolds include porosity degree, pore size average, and interconnections. As a result, pore sizes in the range of 100 to $40 \mu \mathrm{m}$ are essential for nutrient accessibility, waste discharge, angiogenesis, and ultimately tissue regeneration [21]. Our finding showed that PLGA scaffold synthesized in this study could have mild compatibility for cell accommodation.
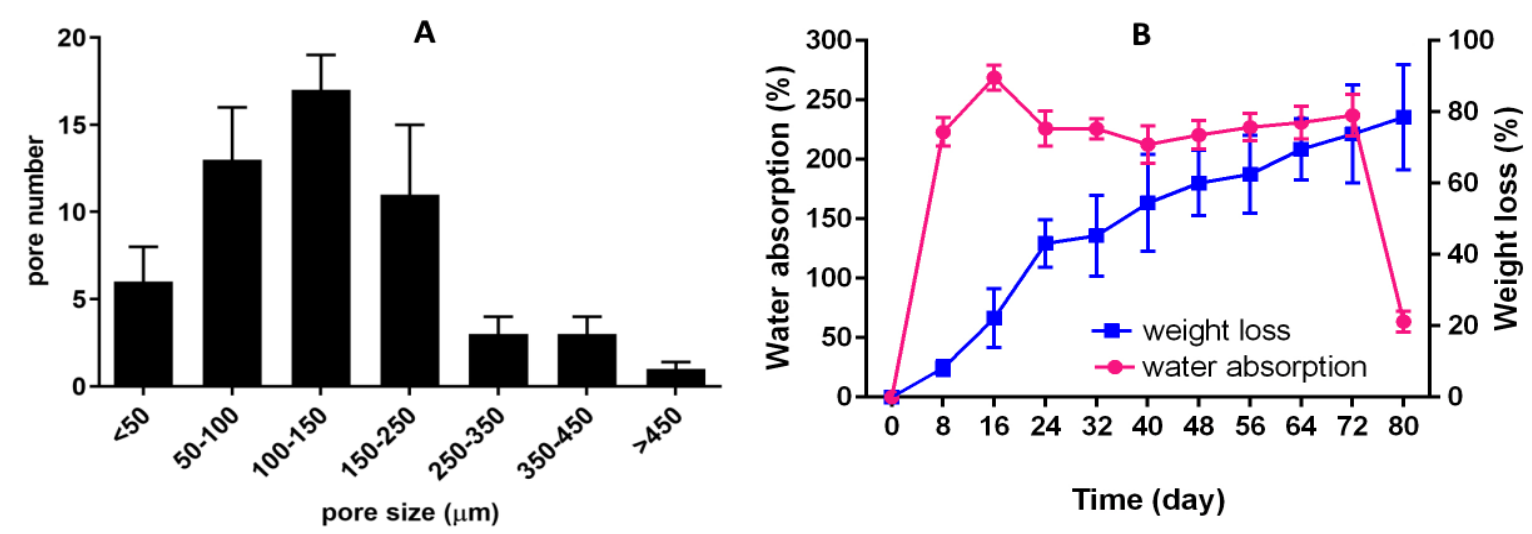

Figure 2. A) Pore size distribution in PLGA scaffolds. B) Water absorption and weight loss from the PLGA scaffold as a function of time. Each point represents the mean of triplicate results at the time range of 8-h.

\subsection{Cell compatibility of the PLGA scaffold.}

Microscope images confirmed the adhesion and proliferation of living cells on the PLGA scaffold. As shown in Figure 3, LNCaP cells proliferated on the PLGA scaffold over 14 days. The biocompatibility of PLGA scaffolds was well-documented by changes in cell morphology from spherical to fibroblasts. SEM images also confirmed LNCaP cells' adhesion to the surface of PLGA scaffolds with good growth potential and implantation in the scaffold structure (Figure 3). As mentioned many the literature, PLGA polymer is an excellent 
biocompatible scaffold for tissue engineering, especially differentiation of stem cells to various functional cells $[22,23]$.
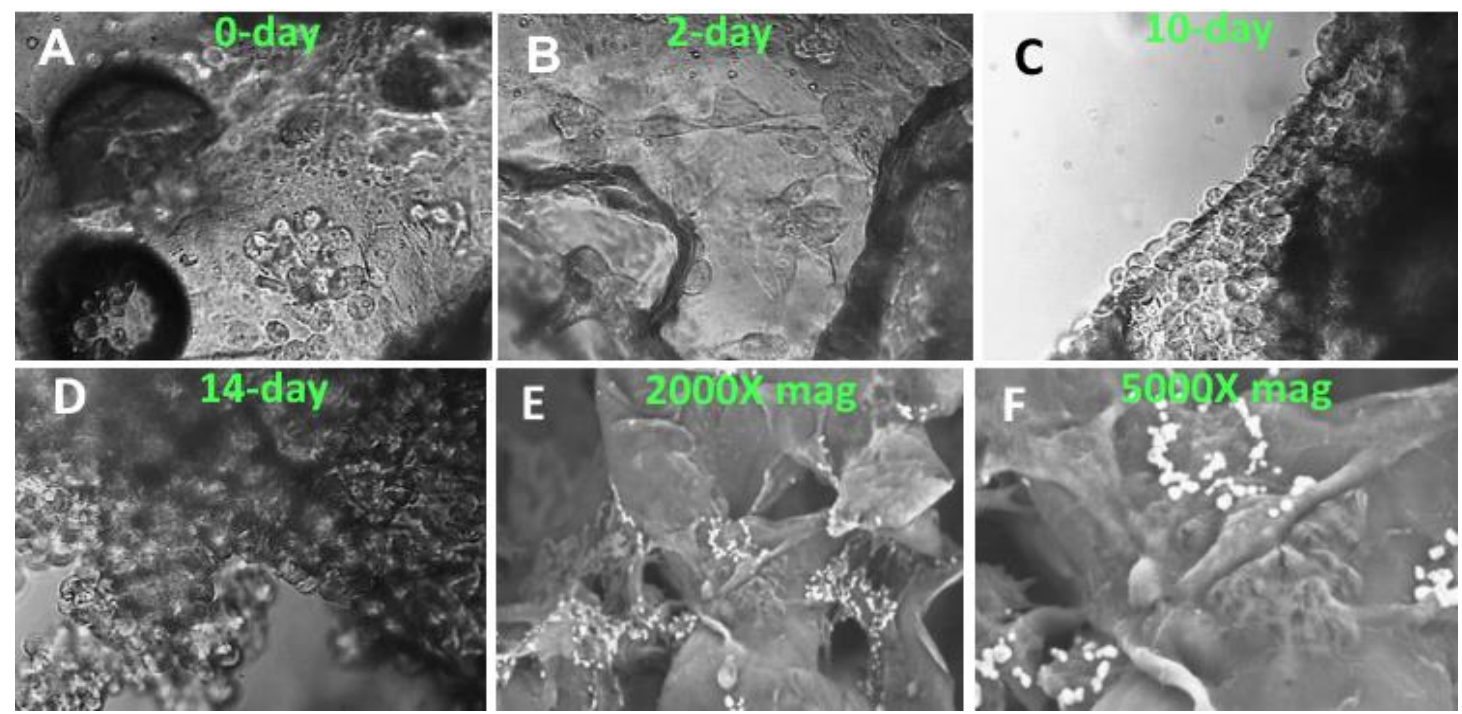

Figure 3. Attachment of LNCaP cells to the PLGA scaffold. (A) Immediately after cell culture, (B) on the second day, LNCaP cells resemble fibroblasts that form on the scaffold, (C) On day 10, cells proliferate and cover the scaffold, (D) The cell layers are tissue-like, (E) SEM image of PLGA scaffold indicating cell attachment (E) in magnification of 2000X and (F) in magnification of 5000X.

\subsection{Isolation and purification of MSCs.}

After 4 days of incubation, the stem cells formed irregularly around the bone marrow pieces in the flask. The solid fragments of the bone marrow were removed by PBS washing. After trypsinization of the adherent cells, re-incubation was performed for $72 \mathrm{~h}$. The next day, the cells reached a confluency of $100 \%$. Finally, in a multi-step process, MSCs grew as a layer of spherical cells after 8 days (Figure 4).
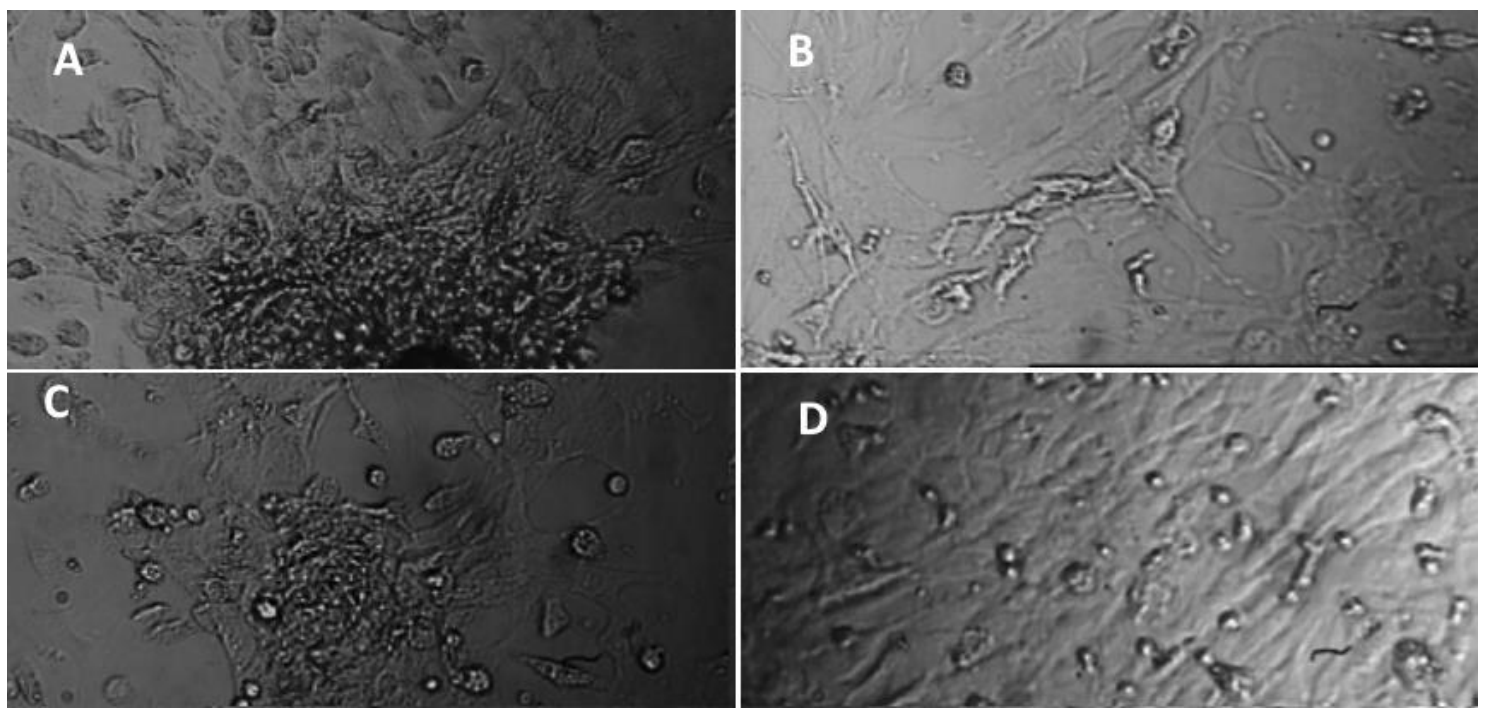

Figure 4. Figure 4. isolation and growth of MSCs. A) after 4 days incubation, B) initial passage of MSCs, C)

$72 \mathrm{~h}$ after the initial passage and D) 4 days after the initial passage and 8 days of isolation time.

MSCs are an essential tissue engineering tool because they are currently used to regenerate various tissues, including bone, stroma, tendon, cartilage, skin, ligaments, and fat [24]. Also, mesenchymal stem cells have promising therapeutic and anti-inflammatory effects 
due to their high potential to secrete active molecules, including growth stimulants and tissue repair agents $[25,26]$.

\subsection{MSCs seeding and differentiating onto PLGA scaffold.}

In this study, the PLGA-based scaffold has effectively imitated the natural tissue structure's properties, enabling MSCs to grow and differentiate on the scaffold. As shown in Figure 5, after 21 days of cultivation, the scaffold-attached cells significantly increased. The results showed that MSCs differentiate on the scaffold to fibroblasts and become spherical in high cell density areas. One of the most important biological factors in the proliferation and differentiation of eukaryotic cells is their adhesion to the surface [8]. The results show that PLGA-based scaffolds increase cell adhesion due to their high porosity [6].

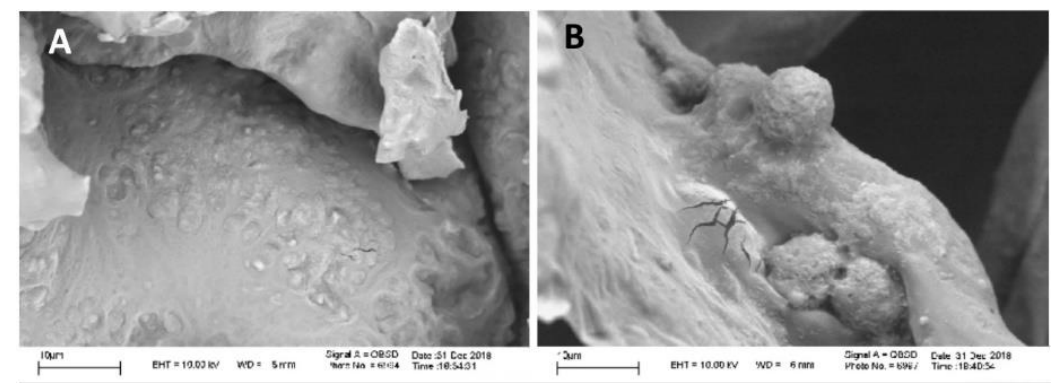

Figure 5. SEM image of cells on the PLGA scaffold. A) The marginal portion of the PLGA scaffold showing cell attachment. B) The scaffold's cross-sectional area indicates that the cells have penetrated the internal porous structure of the scaffold.

\subsection{Differentiation and mineralization study.}

Optical microscopy images in Figure 6A show that after their induction, MSCs preferentially differentiate into osteoblast cells.

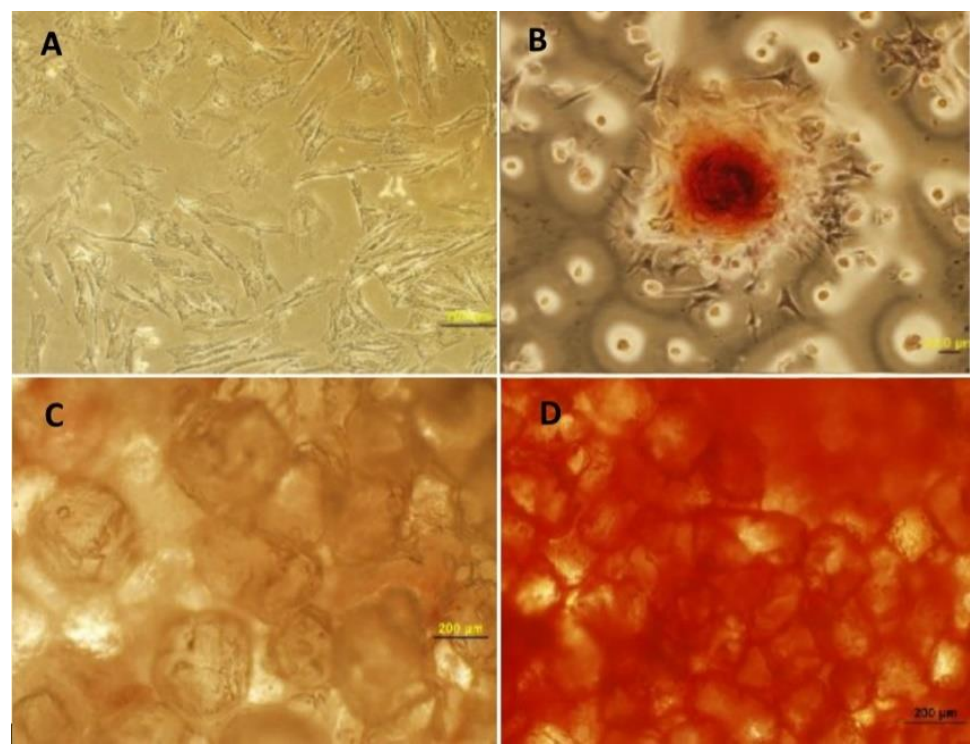

Figure 6. Osteo-differentiation of MSCs. (A) MSCs without differentiation. (B) Free cells differentiated to osteoblasts (C) Scaffold without cell seeding as negative control and (D) Calcium deposition stained with Alizarin Red due to Osteo-differentiation of MSCs.

Also, the ability of MSCs to survive on the scaffold and respond to osteogenic differentiation was confirmed by Alizarin red staining. Figure 6a shows undifferentiated MSCs 
without staining by Alizarin. In contrast, Figure 6b shows the effect of osteogenic factors on MSCs differentiation to osteoblasts. Polymeri et al. (2016) showed that PLGA-based scaffolds, due to improved hydrophilicity, interconnected porous structure, and biodegradability are known as promising substrate for tissue regeneration by MSCs [27].

\subsection{Molecular analysis of differentiation.}

Differentiated genes, including Ops and Alp, were studied to assess osteoblastic differentiation of MSCs on the scaffold-attached cells. The Ops gene expression was not observed after the first week in the differentiation-induced medium, while after 2 weeks of induction, the Ops gene was significantly expressed (Fig 7A). As shown in Figure 7B, Alp gene expression begins at the end of the third week (Figure 7B). Actin gene expression was a reliable control to confirm the findings of this experiment (Figure 7C). Literature reveals that the development of osteoblasts from mesenchymal stem cells is associated with increased expression of the ALP and Ops genes. However, studies indicate that the process of differentiation in mesenchymal stem cells could indeed occur progressively. Birmingham et al. (2012) concluded that stem cell differentiation is directly attributed to greater Alp expression and calcium accumulation [28]. However, evidence demonstrates that osteocyte formation functions as a transitional step in the development of osteoblast formation. The expression of osteogenic genes such as ALP and Ops does not alter noticeably in the early stages of stem cell differentiation. In this regard, our results are consistent with Biswas et al. (2018), indicating a multi-step differentiation mechanism for MSCs [29].
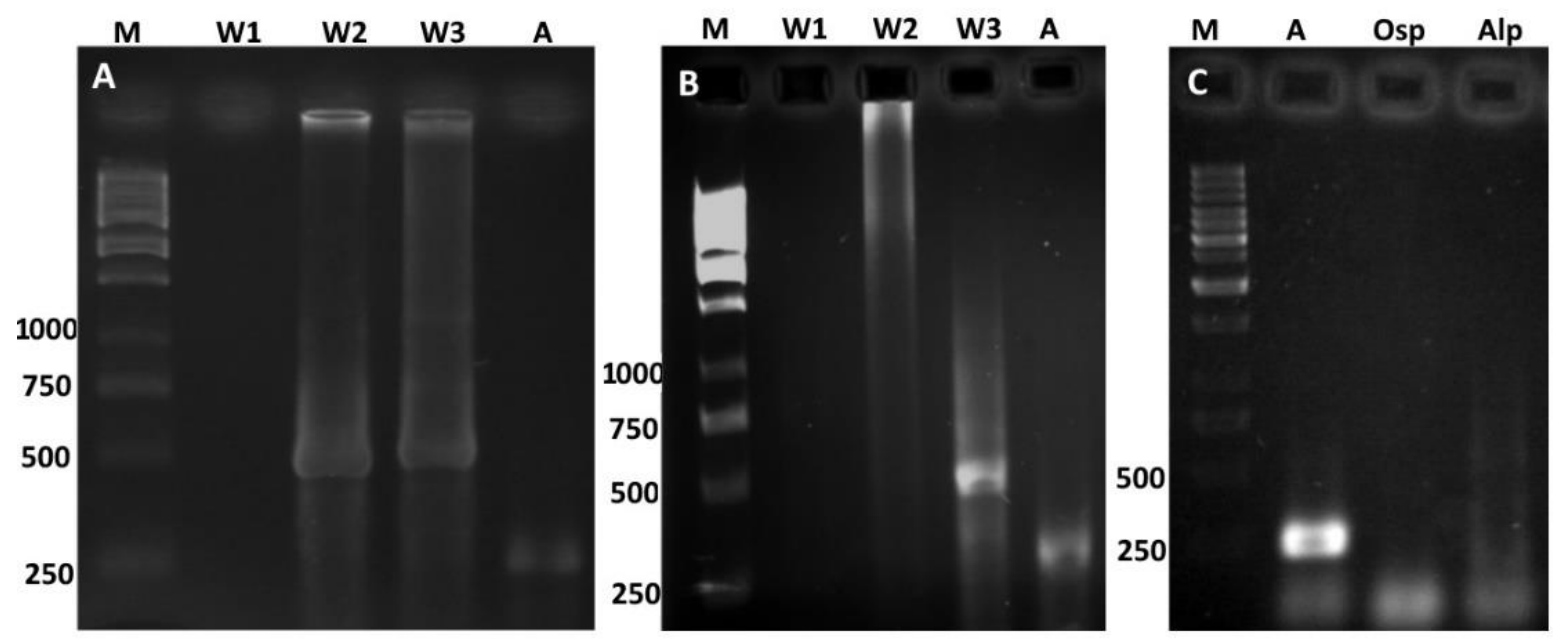

Figure 7. Expression of differentiative genes in osteogenic cells. (A) Ops gene expression at the end of the first (W1), second (W2) and third (W3) weeks. (B) The expression of Alp gene at the end of the first (W1), second (W2), and third (W3) weeks and (C) expression of Ops and Alp genes in MSCs as a negative control without differentiation induction. Expression of the housekeeping gene, actin (A), was considered as an internal control.

\section{Conclusions}

This study fabricated a PLGA-based polymer scaffold for mesenchymal stem cells' growth and differentiation into specialized osteoblast cells. The constructed scaffolds' physicochemical properties showed promising surface properties and mechanical properties to increase MSC proliferation and bone differentiation. Taken together, this study established PLGA-based scaffolding that could be potentially safe and compatible for developing tissue engineering scaffolds, implants, and drug delivery systems. 


\section{Funding}

This work was financially supported by the University of Mohaghegh Ardabili, Ardabil-Iran.

\section{Acknowledgments}

This research has no acknowledgment.

\section{Conflicts of Interest}

The authors declare no conflict of interest.

\section{References}

1. Khademhosseini, A.; Langer, R. A decade of progress in tissue engineering. Nature protocols 2016, 11, 1775-1781, https://doi.org/10.1038/nprot.2016.123.

2. Guo, B.; Ma, P.X. Conducting polymers for tissue engineering. Biomacromolecules 2018, 19, 1764-1782, https://doi.org/10.1021/acs.biomac.8b00276.

3. Roseti, L.; Parisi, V.; Petretta, M.; Cavallo, C.; Desando, G.; Bartolotti, I.; Grigolo, B. Scaffolds for bone tissue engineering: state of the art and new perspectives. Materials Science and Engineering: C 2017, 78, 1246-1262, https://doi.org/10.1016/j.msec.2017.05.017.

4. Nicolae, A. Strategies based on stem cells for tissue engineering. Biomaterials and Tissue Engineering Bulletin 2018, 5, 91-96, https://doi.org/10.33263/BTEB512.091096.

5. Wang, W.; Jin, S.; Ye, K.J.S.C. Development of islet organoids from H9 human embryonic stem cells in biomimetic 3D scaffolds. Stem Cells Development 2017, 26, 394-404, https://doi.org/10.1089/scd.2016.0115.

6. Cristina, C. Tissue engineered vascular grafts. Biomaterials and Tissue Engineering Bulletin 2018, 5, 110118, https://doi.org/10.33263/BTEB534.110118.

7. Ghalia, M.A.; Dahman, Y. Biodegradable poly (lactic acid)-based scaffolds: synthesis and biomedical applications. Journal of Polymer Research 2017, 24, https://doi.org/10.1007/s10965-017-1227-2.

8. Florea, D.F.; Andronescu, E.; Grumezescu, A.M. Innovative biomaterials in bone tissue engineering. Materials International 2019, 1, 0002-0012, https://doi.org/10.33263/Materials11.002012.

9. Pattaro, A.F.; Bahú, J.O.; Schiavon, M.I.R.B.; Gabriel, L.P.; Concha, V.O.C.; Jardini, A.L.; Maciel Filho, R.J.M.I. Poly (L-Lactide-co-Glycolide)(PLLGA)-fast synthesis method for the production of tissue engineering scaffolds. Materials International 2020, 2, 0286-0296.

10. Oh, HJ.; Kim, SH.; Cho, JH.; Park, SH.; Min, BH. Mechanically reinforced extracellular matrix scaffold for application of cartilage tissue engineering. Tissue Engineering and Regenerative Medicine 2018, 15, $287-$ 299, https://doi.org/10.1007/s13770-018-0114-1

11. Babilotte, J.; Guduric, V.; Le Nihouannen, D.; Naveau, A.; Fricain, J.C.; Catros, S. 3D printed polymermineral composite biomaterials for bone tissue engineering: Fabrication and characterization. Journal of Biomedical Materials Research Part B: Applied Biomaterials 2019, 107, 2579-95, https://doi.org/10.1002/jbm.b.34348

12. Sukanya, V.S.; Mohanan, P.V. Degradation of Poly ( $\varepsilon$-caprolactone) and bio-interactions with mouse bone marrow mesenchymal stem cells. Colloids and Surfaces B: Biointerfaces. 2018, 163, 107-118, https://doi.org/10.1016/j.colsurfb.2017.12.039

13. Kim, H.Y.; Kim, H.N.; Lee, S.J.; Song, J.E.; Kwon, S.Y.; Chung, J.W.; Lee, D.; Khang, G. Effect of pore sizes of PLGA scaffolds on mechanical properties and cell behaviour for nucleus pulposus regeneration in vivo. Journal of Tissue Engineering and Regenerative Medicine 2017, 11, 44-57.

14. Dorati, R.; Colonna, C.; Genta, I.; Modena, T.; Conti, B. Effect of porogen on the physico-chemical properties and degradation performance of PLGA scaffolds. Polymer Degradation Stability 2010, 95, 694701, https://doi.org/10.1016/j.polymdegradstab.2009.11.039.

15. Duval, K.; Grover, H.; Han, L.-H.; Mou, Y.; Pegoraro, A.F.; Fredberg, J.; Chen, Z. Modeling physiological events in 2D vs. 3D cell culture. Physiology 2017, 32, 266-277, https://doi.org/10.1152/physiol.00036.2016.

16. Nikolova, M.P.; Chavali, M.S. Recent advances in biomaterials for 3D scaffolds: A review. Bioactive materials 2019, 4, 271-292, https://doi.org/10.1016/j.bioactmat.2019.10.005.

17. Wang, T.; Xue, P.; Wang, A.; Yin, M.; Han, J.; Tang, S.; Liang, R. Pore change during degradation of octreotide acetate-loaded PLGA microspheres: The effect of polymer blends. European Journal of Pharmaceutical Sciences 2019, 138, https://doi.org/10.1016/j.ejps.2019.104990.

18. Gu, B.; Sun, X.; Papadimitrakopoulos, F.; Burgess, D.J. Seeing is believing, PLGA microsphere degradation revealed in PLGA microsphere/PVA hydrogel composites. Journal of controlled release 2016, 228, 170178, https://doi.org/10.1016/j.jconrel.2016.03.011. 
19. Machatschek, R.; Lendlein, A. Fundamental insights in PLGA degradation from thin film studies. Journal of controlled release 2020, 319, 276-284, https://doi.org/10.1016/j.jconrel.2019.12.044.

20. Chen, W.; Palazzo, A.; Hennink, W.E.; Kok, R.J. Effect of particle size on drug loading and release kinetics of gefitinib-loaded PLGA microspheres. Molecular pharmaceutics 2017, 14, 459-467, https://doi.org/10.1021/acs.molpharmaceut.6b00896.

21. Cheng, T.; Qu, H.; Zhang, G.; Zhang, X. Osteogenic and antibacterial properties of vancomycin-laden mesoporous bioglass/PLGA composite scaffolds for bone regeneration in infected bone defects. Artificial Cells, $\quad$ Nanomedicine, $\quad$ Biotechnology $\quad \mathbf{2 0 1 8 ,} \quad 46, \quad$ 1935-1947, https://doi.org/10.1080/21691401.2017.1396997.

22. Tan, J.; Liu, L.; Li, B.; Xie, Q.; Sun, J.; Pu, H.; Zhang, L. Pancreatic stem cells differentiate into insulinsecreting cells on fibroblast-modified PLGA membranes. Materials Science Engineering: C 2019, 97, 593601, https://doi.org/10.1016/j.msec.2018.12.062.

23. Ding, D.; Zhu, Q. Recent advances of PLGA micro/nanoparticles for the delivery of biomacromolecular therapeutics. Materials Science Engineering: $\quad C \quad$ 2018, 92, 1041-1060, https://doi.org/10.1016/j.msec.2017.12.036.

24. Zhou, L.; Tu, J.; Fang, G.; Deng, L.; Gao, X.; Guo, K.; Kong, J.; Lv, J.; Guan, W.; Yang, C. Combining PLGA Scaffold and MSCs for Brain Tissue Engineering: A Potential Tool for Treatment of Brain Injury. Stem Cells International 2018, 2018, https://doi.org/10.1155/2018/5024175.

25. Li, H.; Shen, S.; Fu, H.; Wang, Z.; Li, X.; Sui, X.; Yuan, M.; Liu, S.; Wang, G.; Guo, Q. Immunomodulatory functions of mesenchymal stem cells in tissue engineering. Stem Cells International 2019, 2019, https://doi.org/10.1155/2019/9671206.

26. Kwon, S.G.; Kwon, Y.W.; Lee, T.W.; Park, G.T.; Kim, J.H. Recent advances in stem cell therapeutics and tissue engineering strategies. Biomaterials Research 2018, 22, 1-8, https://doi.org/10.1186/s40824-0180148-4.

27. Polymeri, A.; Giannobile, W.; Kaigler, D. Bone marrow stromal stem cells in tissue engineering and regenerative medicine. Hormone Metabolic Research 2016, 48, 700-713, https://doi.org/10.1055/s-0042118458.

28. Birmingham, E.; Niebur, G.; McHugh, P.E. Osteogenic differentiation of mesenchymal stem cells is regulated by osteocyte and osteoblast cells in a simplified bone niche. European Cells Materials 2012, 23, 13-27, https://doi.org/10.22203/eCM.v023a02.

29. Biswas, S.; Li, P.; Wu, H.; Shafiquzzaman, M.; Murakami, S.; Schneider, M. D.; Mishina, Y.; Li, B.; Li, J. BMPRIA is required for osteogenic differentiation and RANKL expression in adult bone marrow mesenchymal stromal cells. Scientific Reports 2018, 8, 1-14, https://doi.org/10.1038/s41598-018-26820-8. 